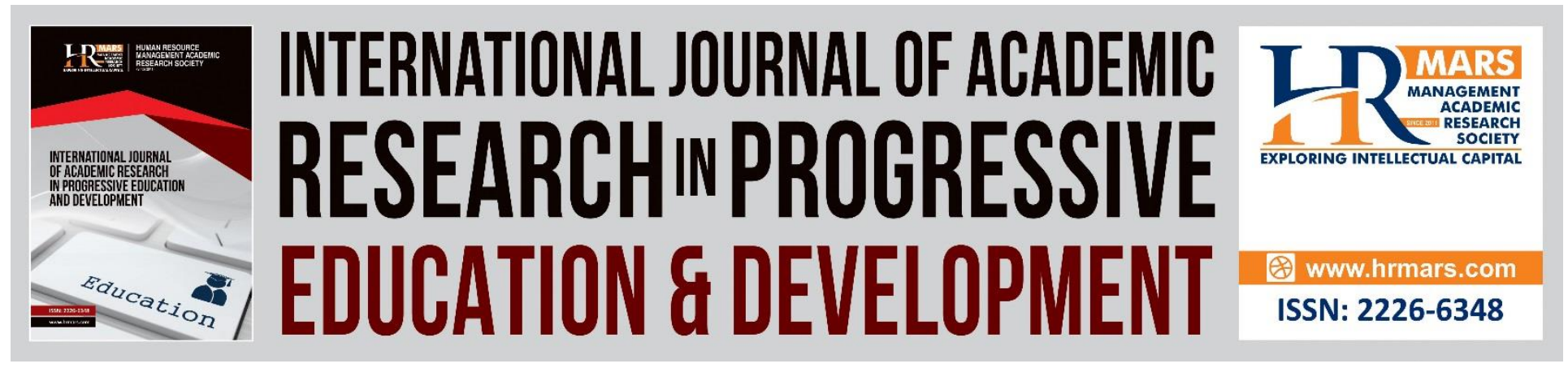

\title{
Satisfied with Online Learning Amidst COVID-19, but do you Intend to Continue Using it?
}

\author{
Ellen Chung, Vloreen Nity Mathew
}

To Link this Article: http://dx.doi.org/10.6007/IJARPED/v9-i4/8177

DOI:10.6007/IJARPED/v9-i4/8177

Received: 20 October 2020, Revised: 21 November 2020, Accepted: 12 December 2020

Published Online: 29 December 2020

In-Text Citation: (Chung \& Mathew, 2020)

To Cite this Article: Chung, E., \& Mathew, V. N. (2020). Satisfied with Online Learning Amidst COVID-19, but do you Intend to Continue Using it? International Journal of Academic Research in Progressive Education and Development, 9(4), 67-77.

Copyright: (C) 2020 The Author(s)

Published by Human Resource Management Academic Research Society (www.hrmars.com)

This article is published under the Creative Commons Attribution (CC BY 4.0) license. Anyone may reproduce, distribute, translate and create derivative works of this article (for both commercial and non-commercial purposes), subject to full attribution to the original publication and authors. The full terms of this license may be seen at: $\underline{\text { http://creativecommons.org/licences/by/4.0/legalcode }}$

Vol. 9(4) 2020, Pg. 67 - 77

http://hrmars.com/index.php/pages/detail/IJARPED

JOURNAL HOMEPAGE

Full Terms \& Conditions of access and use can be found at http://hrmars.com/index.php/pages/detail/publication-ethics 


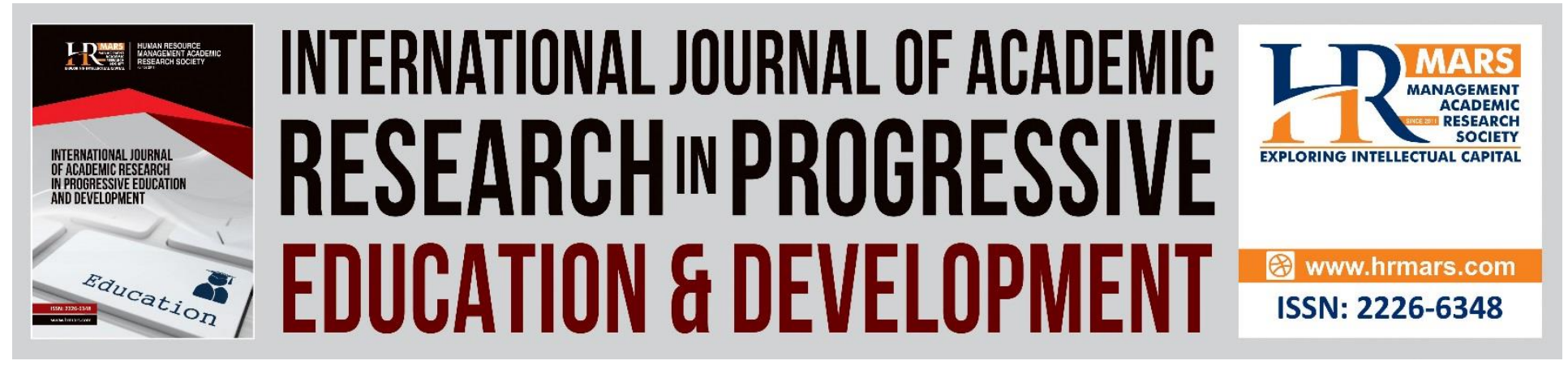

\title{
Satisfied with Online Learning Amidst COVID-19, but do you Intend to Continue Using it?
}

\author{
Ellen Chung, Vloreen Nity Mathew \\ Faculty of Business and Management Universiti Teknologi MARA, Cawangan Sarawak \\ Jalan Meranek 94300 Kota Samarahan Sarawak Malaysia \\ Email: ellencsm@uitm.edu.my
}

\begin{abstract}
The success of online learning programs depends not only on students' satisfaction, but also their intent to continue using it. This study is aimed at finding out if university students' gender, study program, geographical location and internet connection have an effect on their online learning satisfaction and intention to continue using online learning in the future during the COVID-19 pandemic. Data collected from 608 students using simple random sampling from several campuses of Universiti Teknologi MARA Malaysia was analysed using frequency, crosstabulation, Chi-square test and multiple regression analysis methods. The findings revealed that six in every ten respondents are satisfied with their online learning, but the same amount of students do not intend to continue using online learning in the future. Female students, degree students, students from East Malaysia of Sabah and Sarawak, and students with good internet connection are satisfied with online learning. As for their intention to continue using online learning in the future, more male, diploma and West Malaysian students with average internet connection do not intend to do so in the future. Apart from that, online learning satisfaction is a significant predictor of students' intention to continue with online learning in the future. Direction for future studies and practical implications of the study are also discussed.
\end{abstract}

Keywords: Online Learning Satisfaction, Intention to Continue, Covid-19, Internet Connection

\section{Introduction}

Higher education all over the world has been affected by COVID-19 pandemic in many ways. In Malaysia, all teaching and learning activities in universities were moved online within a very short time since April 2020. After being thrown into the deep end of online learning, university students and lecturers had to adopt online learning for three months from April 2020 until June 2020. By September 2020, the COVID-19 condition seemed to have been brought under control. Most universities began to prepare in earnest to welcome students back to the campus in October 2020. However, due to a sudden surge in the number of positive cases, face-to-face learning was put on hold, again. University students once again had to use online learning indefinitely. It is undeniable that online learning has become the best solution to ensure continuity in learning. 
However, several studies have highlighted teething problems in relation to online learning. Not all university students are ready for online learning due to lack of learners control, self-directed learning and online communication efficacy (Chung, Supramaniam \& Dass, 2020b), poor internet connectivity and limited broadband data remained the biggest challenges (Chung, Noor and Mathew, 2020a), many academics, especially the Generation X and some Baby Boomers were not able to cope with the demand of technology competency and proficiency apart from the heavy workload (Gillet-Swan, 2017), home was not a productive place for online learning, level of understanding of subject matter, lack of meaningful interactions among students and instructors lead to lack of learning motivation (Mishra, Gopta \& Shree, 2020). Although satisfaction is a key concern for most educational institutions and instructions, there are limited studies about students' self-reported online learning satisfaction and intention to continue using online learning during the COVID-19 pandemic. This study is aimed at finding out if university students' gender, study program, geographical location and internet connections have an effect on their online learning satisfaction and intention to continue using online learning in the future. The following research questions steer the direction on this study.

1. Is there any difference in online learning satisfaction for university students of different gender, study program, location and internet connectivity?

2. Is there any difference in intention to continue using online learning for university students of different gender, study program, location and internet connectivity?

3. What is the relationship between online learning satisfaction, internet connection and intention to continue with online learning among university students?

\section{Online Learning Satisfaction}

Research has shown that online learning has many advantages and benefits (Shen \& Chuang, 2010). Among them are related to providing time and place flexibility; resulting in cost and time savings for educational institutions; fostering self-directed and self-paced learning by enabling learner-centred activities; creating a collaborative learning environment by linking each learner with physically dispersed experts and peers; and allowing knowledge to be maintained and updated in a more timely and efficient manner. The success of an online learning program depends not only on students' satisfaction but also their intent to continue using it. Studies have shown that satisfied students appear to be engaged, motivated and responsive; contribute to an effective learning climate; and achieve higher levels of performance. On the contrary, dissatisfied or ambivalent students results in situations where instructors appear to have much more difficulty facilitating effective learning situations (Dziuban, Moskal, Kramer \& Thompson, 2007). As online learning grows by leaps and bounds since the COVID-19 pandemic, it is imperative for instructors and institutions to find out students' online learning satisfaction and intention to continue using it. Over the years, various researchers have used different yardsticks to measure these concepts. Jung, Chio, Lim \& Leem (2012) use students' final grades, course completion rates, student' attitudes toward online classes while Seiver \& Trojar (2014) make use of students' self-reports of satisfaction in relation to course quality, interaction/ communication and learners' characteristics. Mahmood, Mahmood and Malik (2012) argued that teaching presence plays the most critical role in how students evaluate online learning. The interaction construct plays an 
important role in both face-to-face and online learning modalities (Kuo, Walker, Belland \& Schroder, 2013). On the other hand, five elements of student satisfaction: learner relevance, active learning, authentic learning, learner autonomy, and technology competence were identified by Ke and Kwak (2013).

\section{Intention to Continue using Online Learning}

From the literature search, most of the studies conducted that examine the antecedents of intention to use online learning either use Technology Acceptance Model (TAM) developed by Davis (1989), or Unified Theory of Acceptance and Use of Technology (UTAUT) formulated by Venkatesh, Morris, Davis \& Davis, 2003), or Theory of Planned Behaviour (TPB) by Ajzen (1985). TAM looks at various variables such as perceived usefulness, perceived ease of use, behavioural intention and actual use of technology. UTAUT on the other hand investigates user behaviour intention based performance expectancy, effort expectancy, social influence and facilitating conditions of a technology. Samat, Awang, Hussin \& Nawi (2020) found that there was a positive and significant relationship between performance expectancy, social influence, facilitating condition, intrinsic value and behavioural intention to use online learning. On the other hand, TPB looks at attitude, subjective norm and perceived behavioural control that affects behavioural intention and actual usage of a product or service. It is important to note that in this study, none of the above theory or model is used. In fact, the intention to continue to use online learning is measured using a single-item measure which will be further explained in the methodology section.

\section{Internet Connection}

Likewise for internet connection, a search in the literature revealed very limited reports in relation to internet connection and intention to continue using online learning. This could be due to the fact that good and stable internet connection is one of the most basic building blocks for successful online learning activities. However the untimely COVID-19 pandemic has thrown all face-to-face teaching and learning activities off the cliff. This has left many countries with such challenges scrambling to find other ways to reach students to ensure continuity of education. Even before Malaysian students were coerced into adopting online learning due to COVID-19 pandemic, internet connection has been, and remains a major online learning challenge (Chung et al, 2020b). In Sabah and Sarawak, this issue is even more pressing ever since all teaching and learning have been moved online since April 2020. Many have urged the federal government to improve the internet connectivity in these two states (see Lee, 2020; Tawie, 2020). Until more stable internet infrastructure is ready, university students who reside in rural Sabah and Sarawak will continue be plagued by these challenges.

\section{Methodology}

It is important to note that this paper presents only one small part of findings of what was a bigger research scope. This paper focuses on investigating university students' online learning satisfaction and intention to continue using online learning for the coming semesters. At the time when data was collection, there was no indication from the universities nor higher authorities that online learning would be continued. Google Form containing questionnaire was sent out to 
about 700 students of Universiti Teknologi MARA (UiTM) in June 2020. These students were from two campuses in East Malaysia and three campuses in West Malaysia. A simple random sampling approach was used where the researchers sought assistance from several colleagues from these campuses to send the Google Form out to their respective students whom they were teaching. The respondents in this study were online learning students enrolled in both degree and diploma study programs. They were asked to describe themselves in reference to a 6-point scale, with 1 (very dissatisfied) and 6 (very satisfied) for online learning satisfaction, and 1(strongly disagree) and 6 (strongly agree) for intention to continue using online learning in the future. In both of these response scales, the bigger the scale, the higher the online satisfaction and intention to continue to use online learning in the future. A total of 608 completed Google Form was returned, cleaned and transferred to SPSS and analysed. Some of analysis methods include frequency analysis, crosstabulation, Chi-square test and multiple regression analysis. For this study, a singleitem construct to measure students' online learning satisfaction and intention to continue using online learning has been adopted. Although many argued the reliability and validity of singleitem measures, Wanous, Reichers \& Hudy (1997) have proven that single-item measures are valid and reliable, without denying the same of multi-dimensions and multi-items measures.

\section{Findings and Discussions}

As shown in Table 1, the 608 respondents were made up of 216 (35.5\%) male and 392 (64.5\%) female students. They ranged from 19 to 25 years old with an average age of 21 . While 96 (15.8\%) were diploma students who enrolled in Fundamentals of Management, some 77 (12.7\%) were in Entrepreneurship, another 36 (5.9\%) in Principles of Marketing, and 178 (29.3\%) in Economics and 221 (36.3\%) are degree students enrolled in Human Resource Management. In terms of geographical location, some 430 (70.7\%) were students who reside in East Malaysia of Sarawak and Sabah while 178(29.3\%) were from various states in West Malaysia. Although an equal number of Google Forms containing the questionnaire were sent out to East Malaysian and West Malaysian campuses, due to MCO, students were back in their own home states when data was collected, thus an imbalance in terms of geographical location of respondents was noted. As internet connectivity has been one of the major challenges faced by students in Malaysia, the findings showed that $46.9 \%$ had good internet connectivity while $53.1 \%$ had average connectivity. 
Vol. 9, No. 4, 2020, E-ISSN: $2226-6348$ @ 2020 HRMARS

Table 1. Demographic background of respondents

\begin{tabular}{llll}
\hline & & $\mathrm{n}$ & $\%$ \\
\hline Gender & Male & 216 & 35.5 \\
Program & Female & 392 & 64.5 \\
& Degree & 221 & 36.3 \\
Courses & Diploma & 387 & 63.7 \\
& Fundamentals of Management & 96 & 15.8 \\
& Entrepreneurship & 77 & 12.7 \\
& Principals of Marketing & 36 & 5.9 \\
& Economics & 178 & 29.3 \\
Geographical Location & Human Resource Management & 221 & 36.3 \\
& Sabah \& Sarawak & 430 & 70.7 \\
& West Malaysia & 178 & 29.3 \\
& Good & 285 & 46.9 \\
\hline
\end{tabular}

In this study, two dependent variables and four independent variables are discussed. These two dependent variables are online learning satisfaction and intention to continue using online learning in the future. The four independent variables are respondents' gender, study program, geographical location and internet connectivity. The responses were transformed to dichotomous data for more meaningful interpretations. For online learning satisfaction, responses which ranged from 1 being "very dissatisfied" to 6 being very "satisfied", scale 1 to 3 was transformed to "dissatisfied", scale 4 to 6 was transformed to "satisfied". The same procedure was used to transform intention to continue using online learning. As depicted in Table $2,61.5 \%$ of them were satisfied with online learning. However, when asked if they intent to continue to use online learning in the future, $61.5 \%$ of them disagreed.

Table 2. Online learning satisfaction and intention to continue using online learning

\begin{tabular}{|c|c|c|c|c|}
\hline \multicolumn{5}{|l|}{ Item } \\
\hline \multirow[t]{3}{*}{ Online learning satisfaction } & \multicolumn{2}{|c|}{ Dissatisfied } & \multicolumn{2}{|c|}{ Satisfied } \\
\hline & $\mathrm{n}$ & $\%$ & $\mathrm{n}$ & $\%$ \\
\hline & 234 & 38.5 & 374 & 61.5 \\
\hline \multirow[t]{3}{*}{ Intention to continue using online learning in the future } & \multicolumn{2}{|c|}{ Disagree } & \multicolumn{2}{|c|}{ Agree } \\
\hline & $\mathrm{n}$ & $\%$ & $\mathrm{n}$ & $\%$ \\
\hline & 373 & 61.3 & 235 & 38.7 \\
\hline
\end{tabular}

In order to answer the first research question, frequency analyses were used to investigate the online learning satisfaction among respondents of different gender, study programs, geographical locations and internet connection. As depicted in Table 3, 56.5\% of males students and $64.3 \%$ of female students were satisfied with online learning. As for study program, $83 \%$ of degree students indicated that they were satisfied while $76 \%$ of diploma students said they were not satisfied with online learning. As for geographical location, $67.4 \%$ students in East Malaysia 
of Sabah and Sarawak agreed that they are satisfied while slightly more than half of students in West Malaysia were dissatisfied. Slightly more than half of the students with average internet connection are satisfied while close to $70 \%$ of students with good internet connection are satisfied with online learning. Further analysis using Chi-Square test was carried out to investigate if there was any association between the variables in this study. Chi-square analysis results showed that gender, study program and internet connection had significant relationship with online learning satisfaction, with $P=.012, P=.003$ and $P<.001$. However, students' location did not have any significant relationship with online learning satisfaction, $P>.05$

Table 3: Online learning satisfaction by gender, study program, location and internet connection

\begin{tabular}{|c|c|c|c|c|c|}
\hline & \multicolumn{2}{|c|}{ Dissatisfied } & \multicolumn{2}{|c|}{ Satisfied } & \multirow[t]{2}{*}{ Significance level } \\
\hline & $\mathrm{n}$ & $\%$ & $\mathrm{n}$ & $\%$ & \\
\hline \multicolumn{6}{|l|}{ Gender } \\
\hline Male & 94 & 43.5 & 122 & 56.5 & $* .012$ \\
\hline Female & 140 & 35.7 & 252 & 64.3 & \\
\hline \multicolumn{6}{|l|}{ Study Program } \\
\hline Degree & 66 & 17 & 155 & 83 & $* * .003$ \\
\hline Diploma & 168 & 76 & 219 & 24 & \\
\hline \multicolumn{6}{|l|}{ Location } \\
\hline East Malaysia & 140 & 32.6 & 245 & 67.4 & .244 \\
\hline $\begin{array}{l}\text { West Malaysia } \\
\text { Internet } \\
\text { connection }\end{array}$ & 94 & 52.8 & 129 & 47.2 & \\
\hline Good & 87 & 30.5 & 198 & 69.5 & $* * * .000$ \\
\hline Average & 147 & 45.5 & 176 & 54.5 & \\
\hline
\end{tabular}

$* \quad P<.05$

$* * \quad P<.01$

$* * * P<.001$

Is there any difference in intention to continue using online learning for students of different gender, study program, location and internet connectivity? the second research question asks. Table 4 shows more than $60 \%$ of male and female students disagree that they would continue using online learning in the future. As for program level, when analysed within their own groups, up to $57.5 \%$ degree students and $63.6 \%$ diploma students disagreed that they would continue to use online learning in the future. Close to $57 \%$ of students in East Malaysia and $72.5 \%$ of students in West Malaysia disagree. As for students with average internet connection, $64.7 \%$ of them disagrees while $57.5 \%$ of students with good internet connectivity disagrees they would continue to use online learning in the future. Chi-square analysis showed only internet connection had a significant relationship with intention to continue using online learning, $P=.032$, while the other variables did not show any significant relationship with intention to continue using online learning, $P>.05$ 
INTERNATIONAL JOURNAL OF ACADEMIC RESEARCH IN PROGRESSIVE EDUCATION AND DEVELOPMENT

Vol. 9, No. 4, 2020, E-ISSN: $2226-6348$ @ 2020 HRMARS

Table 4: Intention to continue using online learning in the future by gender, study program, location and internet connection

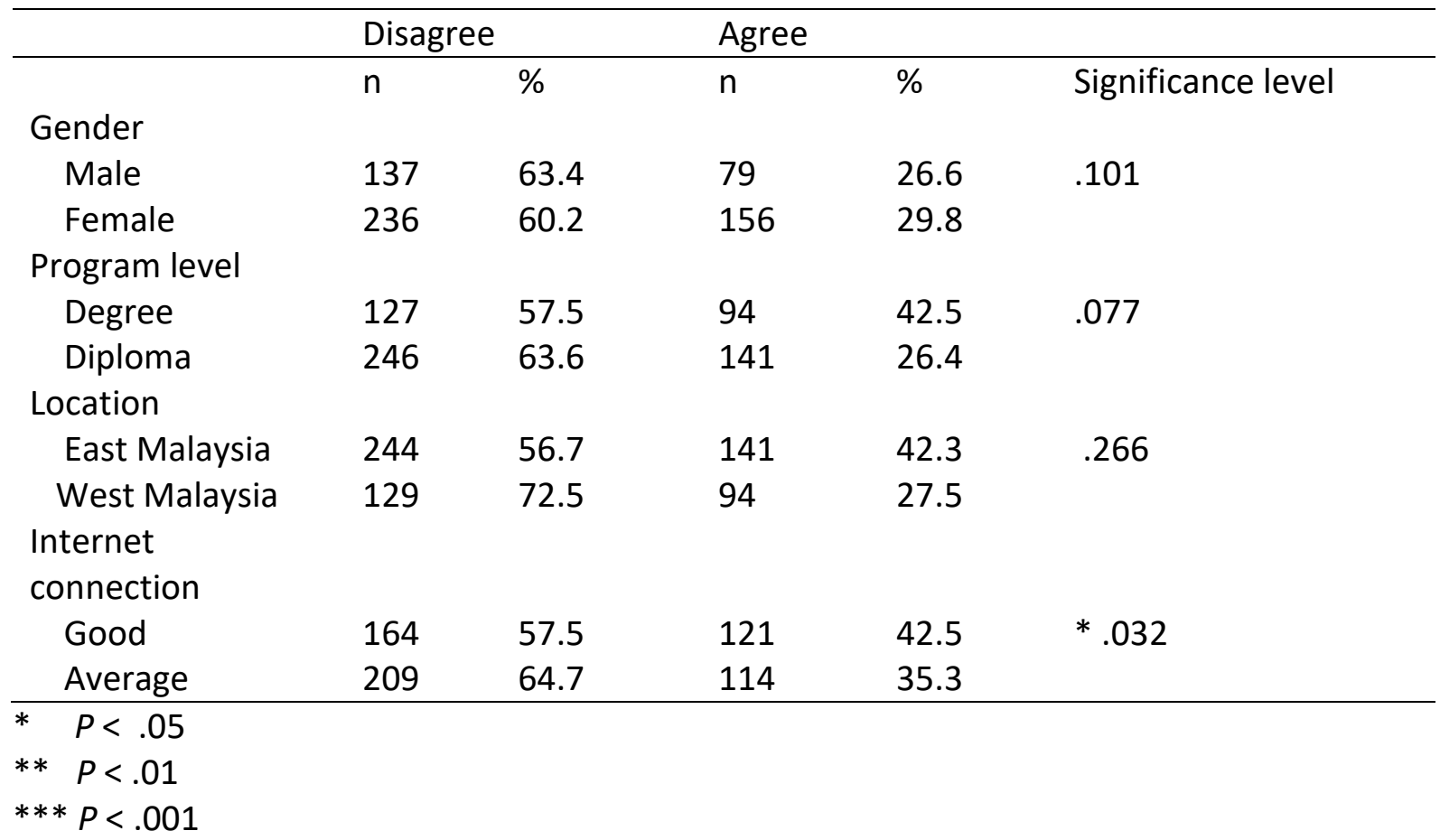

The final research question in this study seeks to investigate the relationship between online learning satisfaction and intention to continue with online learning among the students. Multiple regression analysis was conducted to predict the students' intention to continue using online learning in the future from the variables online learning satisfaction and internet connection, as shown in Table 5. Overall, the regression was significant, $F(2,605)=242.690, p<.05, R^{2}=.445$. This shows that $44.5 \%$ of the variance in student' intention to continue with online learning was contributed by online satisfaction and internet connection. Of the predictors investigated, online learning satisfaction $(\beta=.675, t(605)=21.510, p<.05$ was significant. Internet connection was not a significant predictor of intention to continue with online learning in the future, $\beta=-.034, t$ $(605)=-1.085, p>.05$. The negative beta for internet connection shows that they was an inverse relationship. This shows that if internet is good, their intention to continue to use online learning will increase, and when the internet connection is average, it decreases their intention to continue using online learning.

Table 5. Multiple regression analysis

Model summary

\begin{tabular}{lllll} 
Model & $\mathrm{R}$ & Adjusted R Square & Std. Error of the Estimate & $\begin{array}{l}\text { Std Error of the } \\
\text { Estimate }\end{array}$ \\
\hline 1 & $.667^{\mathrm{a}}$ & .445 & .443 & 1.150 \\
\hline
\end{tabular}

a. Predictors: (Constant), online learning satisfaction, internet connection 
Vol. 9, No. 4, 2020, E-ISSN: $2226-6348$ @ 2020 HRMARS

\section{ANOVA $^{\mathrm{a}}$}

\begin{tabular}{lllllll} 
Model & & Sum of Squares & df & $\begin{array}{l}\text { Mean } \\
\text { Square }\end{array}$ & F & Sig. \\
\hline 1 & Regression & 642.259 & 2 & 321.129 & 242.690 & $.000^{\mathrm{b}}$ \\
& Residual & 800.542 & 605 & 1.323 & & \\
& Total & 1442.801 & 607 & & & \\
\hline
\end{tabular}

a. Dependent variable: Intention to continue using online learning in the future

b. Predictors: (Constant)online learning satisfaction, internet connection

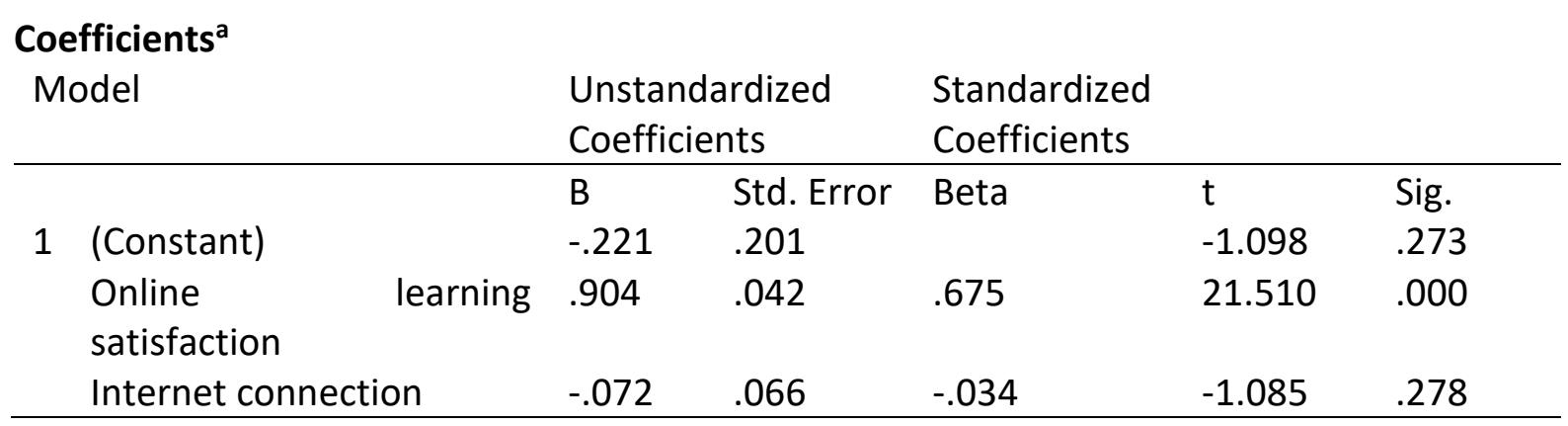

a. Dependent variable: Intention to continue using online learning in the future

\section{Conclusion and Recommendations}

This study set out to investigate if university students' gender, study program, geographical location and internet connection have an effect on their online learning satisfaction and intention to continue using online learning in the future during the COVID-19 pandemic. In line with the objectives of this study, several conclusions could be drawn. Firstly, around six in every ten students were satisfied with their online learning, however, about the same number of students indicated that they did not want to continue using online learning in the future. The findings also revealed that female students, degree students, students from East Malaysia of Sabah and Sarawak, and students with good internet connection were satisfied with online learning. Analysis showed that while gender, study program and internet connection had statistically significant relationship with online learning satisfaction, students' location did not. As for their intention to continue using online learning in the future, findings revealed that more male, diploma and West Malaysian students with average internet connection did not intent to do so. However, only internet connection had a statistically significant relationship with their intention to continue using online learning and internet connection had an inverse relationship with their intention to continue with online learning. The final findings in the study showed that online learning satisfaction was a statistically significant predictor of students' intention to continue with online learning in the future. This study is not without limitations. These limitations coupled with the findings provide ideas for future studies. It is suggested that future studies explore multi-dimensional and multi-items construct to investigate the antecedents, or the factors that could contribute to students online learning satisfaction, as well as areas that contribute to online learning dissatisfaction. Investigation into students' intention to continue to use online learning should use a more holistic research framework such as TAM, UTAUT or Theory of Planned 
Behaviour. Through the understanding of these factors, universities as well as policy makers could provide concrete solutions to improve online learning satisfaction to ensure continuity of quality education. By improving students' online learning satisfaction, it will improve the overall motivation, engagement and performance among university students. For practical implication, internet connection, which is the basic infrastructure to ensure a successful online learning activities, the relevant ministry in the Malaysian government must make haste in resolving this issue to reduce for widening digital divide among the populations.

\section{Reference}

Ajzen, I. (1991). "The theory of planned behavior". Organizational Behavior and Human Decision Processes. 50 (2): 179-211. doi:10.1016/0749-5978(91)90020-T

Chung, E., Noor, N. M., \& Mathew, V. N. (2020a). Are You Ready? An Assessment of Online Learning Readiness among University Students. International Journal of Academic Research in Progressive Education and Development, 9(1), 301-317. DOI: https://doi.org/10.6007/IJARPED/v9-i1/7128.

Chung, E., Supramaniam, G., \& Dass, L. C. (2020b). Online learning edginess among university students in Malaysia amidst Covid-19. Asian Journal of University Education. 16(2), 46-58. DOI: https://doi.org/10.24191/ajue.v16i2.10294.

Davis, F. D. (1989). Perceived usefulness, perceived ease of use, and user acceptance of information technology. MIS Quarterly, 13(3), 319-340.

Dziuban, C., Moskal, P., Kramer, L., \& Thompson, J. (2013). Student satisfaction with online learning in the presence of ambivalence: Looking for the will-o'-the-wisp. Internet and Higher Education, 17, 1-8. doi: 10.1016/j.iheduc.2012.08.001

Gillett-Swan, J. (2017). The challenges of online learning: Supporting and engaging the isolated learner. Journal of Learning Design, 10(1), 20-30. https://doi.org/10.5204/ jld.v9i3.293

Jung, I., Choi, S., Lim, C., and Leem, J., (2002). Effects of different types of interaction on learning achievement, satisfaction and participation in web based instruction. Innovations in Education and Teaching International, 39(2), 153-162.

Ke, F., \& Kwak, D. (2013). Constructs of student-centered online learning on learning satisfaction of a diverse online student body: A structural equation modeling approach. Journal of Educational Computing Research, 48(1), 97-122. doi: 10.2190/EC.48.1.e

Kuo, Y. C., Walker, A. E., Belland, B. R., \& Schroder, K. E. (2013). A predictive study of student satisfaction in online education programs. The International Review of Research in Open and Distance Learning, 14(1), 16-39

Lee, N. (2020). Rural areas to have improves internet connectivity. New Sarawak Tribune. Retrieved from https://www.newsarawaktribune.com.my/rural-areas-to-haveimproved-internet-connectivity

Mahmood, A., Mahmood, S. T., \& Malik, A. B. (2012). A comparative study of student satisfaction level in distance learning and live classroom at higher education level. Turkish Online Journal of Distance Education (TOJDE), 13(1), 128-136.

Mishra, L., Gupta, T., Shree, A. (2020) Online Teaching-Learning in Higher Education during Lockdown Period of COVID-19 Pandemic. (journal in proof)International Journal of Educational Research Open. https://doi.org/10.1016/j.ijedro.2020.100012 
Samat, M. F., Awang, N. A., Hussin, S. N. A., \& Nawi, F. A. M. (2020). Online Distance Learning Amidst Covid-19 Pandemic Among University Students. Asian Journal of University Education, 16(3), 220-233.

Seiver, J. G., and Troja, A. (2014). Satisfaction and success in online learning as a function of the needs for affiliation, autonomy, and mastery. Distance Education, 35(1), 90-10

Shen, C., \& Chuang, H. (2010). Exploring users' attitudes and intentions toward the interactive whiteboard technology environment. International Review on Computers and Software, 5(2), 200-208.

Tawie, S. (2020). Amid spotlights on Sabah. Malay Mail. Retrieved from https://www.malaymail.com/news/malaysia/2020/09/08/amid-spotlight-on-sabahsarawak-pkr-urges-authorities-to-upgrade-internet-c/1901188.

Venkatesh, V., Morris, M. G., Davis, G. B., and Davis, F. D. (2003). User acceptance of information technology: toward a unified view. MIS Q. 27, 425-478.

Wanous, J. P., Reichers, A. E., \& Hudy, M. J. (1997). Overall job satisfaction: how good are singleitem measures? Journal of Applied Psychology, 82(2), 247-252. 